\title{
Social Contract, Authoritarianism and the Dilemma of Africans
}

\author{
Moeketsi Kali \\ Pan African University, Institute of Governance, Humanities and Social Sciences, Cameroon
}

\section{ARTICLE INFO}

\section{Keywords:}

Social Contract

Civil Liberties

Human Rights

Government

Africa

\begin{abstract}
The article expatiates on the social contract to clarify the circumstances leading to despotism, authoritarianism, violation of civil liberties and misery in Africa. It describes the ways in which African leaders violate individual freedoms despite the presence of local laws and international conventions. The article explains the process that led to the misfortune of Africans based on case studies informed by primary and secondary data. It contends that the repercussions of the social contract were underrated due to the dearth of choices. Thus, governments abuse their powers and crush every agent that attempts to provide checks and balances. However, the verdicts of certain local courts and the International Criminal Court demonstrate that strengthening the judicial system can transform the status quo.
\end{abstract}

\section{Introduction}

Citizens living under despotism submit themselves to their authorities for one reason. Coercion does not compel one to yield out of will. Succumbing to vicious leaders is an act of necessity and not a victim's desire. Rousseau (2002) maintains that to yield to force is an act of prudence. The first African slaves who were conquered submitted to their masters because of fear (Klein, 1998; Haskin, 2005). After the abolition of the slave trade in the 1800s, Africans surrendered to their colonial masters because of fear, force and torture. Their cowardice prolonged their misery but courage cast off their colonial chains (Haskin, 2005). After attaining national independence, Haskin (2005) contends that Africans got trapped under dictatorships.

In the past, the wretchedness of Africans stemmed from the brutal force but in modern times it results from unsuccessful conventions. Since powers, authorities and governments are not natural, nobody is born to govern anyone (Rousseau, 2002). It is baffling to understand why Africans tolerate despots, dictators, authoritarians and tyrannies who compel them to live under indecent and deplorable conditions (Bratton \& van de Walle, 1994; Datton, 2017). If it is due to fear, then their misery is justifiable, provided that they are being prudent. However, if a government is based on a convention, it is not clear why citizens cannot reclaim their liberties by virtue of the very right it was taken away. If citizens choose to dismantle their government for anarchism, it means there was no justification to set up a government in the first place (Rousseau, 2002).

Where political covenants are failing, it is either because the international norms are breaking down or the conventions are perverted. The failure of an international convention can only be justifiable in an anarchic international community. Romaniuk and Grice (2018) purport that the rise of competing hegemonic powers within regional blocs and the international system complicates the enforcement mechanisms of conventions. Africans states are signatories to several international human rights treaties but the leaders continue to abuse their powers and violate civil and political rights of citizens (Datton, 2017).

\footnotetext{
* Corresponding author E-mail address: kalimoeketsi@gmail.com 
Based on social contract theory, this article explains ways in which African leaders turn into despots and violate civil and political liberties of citizens. It poses the following questions: How and why did Africans commit themselves under a government? How is the social contract violated in Africa? The author reviews both primary and secondary data and engages in case studies to arrive at conclusions. The sources consulted include books, documents, journals, internet sources, newspapers, constitutions, articles and reports. Drawing from the extant literature, the author maintains that the social contract propounded by Thomas Hobbes, Jean Jacque Rousseau and John Locke which tries to explain the reasons why individuals established a government does not produce the expected outcomes in Africa. The proponents of the social contract theory misjudged the extent to which governments can abuse their powers without limitations.

The first part of this article is an introduction to this discourse and is followed by the approach adopted. The subsequent section explains the process that compelled Africans to establish a government and thereafter a description of the nature of the contemporary social contract. The study further discusses ways in which governments violate the social contract and the one that follows it explains how civil society organizations undermine their responsibility. Finally, the author makes conclusions and recommendations based on the evidence presented in the literature.

\section{The Social Contract Theory: A Justification for Establishing A Government}

According to Hobbes, the conditions of the "state of nature" necessitates the social contract. Before civil society was organized, the security of every human being was not guaranteed despite the strength every person possessed. Everyone was an enemy to another (Hobbes, 1651). The state of nature was characterized by "war of all against all." It was full of injustices because there was no law and common authority (Hobbes, 1651). This was further aggravated by perpetual fear, menace of violent death and life was pathetic, solitary, brutish, nasty and short (Hobbes, 1651).

The rationality imbued in human beings compelled them to reason and find ways of creating a law-governed society (D'Agostino, Gaus \& Thraser, 2019). Human beings recognized that creating a civil society requires them to forgo some rights. They have to mutually transfer their rights and exchange them with a common authority that offers protection (Santilli, 1982). Hence, they had to unanimously agree to renounce the rights or tendencies they had (Hobbes, 1651; Friend, 1995). In doing so, they had to appoint an authority and imbue it with the power to enforce laws to guarantee their civil liberties. Consequently, a government has enforcement mechanisms accompanied by sanctions and penalties.

Contrary to Thomas Hobbes' state of nature where man is perceived as inherently evil, John Locke takes a different approach. According to Locke (1980), in the state of nature, everyone had the executive power of the law of nature. Mankind was guided by the law of nature which is the basis of morality given by God (Verschoor, 2015; Locke, 1980). The morality precludes human beings from harming one another. It dissuades them from divesting others of their possessions and freedoms. The state of nature is, therefore, a relatively peaceful place guided by the law of nature and is not full of cruelty and brutality (Verschoor, 2015).

In the state of nature, anarchy takes place when other human beings extend their freedoms beyond limits and steal the property of others and threaten their liberties (Locke, 1980). As the victims defend their property or revenge, a war begins because there is no civil power to whom they can appeal. This realisation results in the formation of a civil government to defend private property and liberties (Locke, 1980). A political society begins with a conventional agreement which set up authority to punish transgressors of the law of nature found in a moral society (D’Agostino, Gaus \& Thraser, 2019; Santilli, 1982; Locke, 1980). Under the political society, human beings refrain from protecting themselves by punishing others that are a threat. They 
recognize that their freedoms will be protected by the judiciary and executive powers of the government which they instituted through consent (Santilli, 1982; Locke, 1980).

However, John Locke was worried that the sovereign body or authority imbued with absolute authority over people poses a threat to society. Whenever it violates the social contract, it has to be met with a revolution (Locke, 1980). Citizens are justified to resist their political authority whenever it degenerates into tyranny, despotism, dictatorship and authoritarianism (Locke, 1980). They have a right to self-protection against any unfaithful and abusive authority. Citizens can dissolve and replace any regime that devolves into forms of rule that violate the social contract (Locke, 2003; Friend, 1995). In modern society, according to John Locke, the political bonds of citizens are special obligations acquired through the voluntary and deliberate performance of their consensual dealings (Simmons, 1979). This implies that political transactions among people remain legitimate as long as they are done without coercion and do not violate moral standards (Simmons, 1979). Locke (1980) maintained that while preserving liberties, a government should impose sanctions which are equivalent to a crime committed. Punishment has to be severe enough to force a transgressor to repent while threatening others inclined to commit crimes.

Conversely, Jean Jacque Rousseau's perception of the state of nature differs from that of his predecessors in an interesting manner. According to him, when life started, human beings lived in solitude and life was simple. Contrary to Thomas Hobbes, Rousseau (2002) disputes that human beings were natural enemies, one to another. Before plunging himself into the debates concerning the social contract, Rousseau (2002) premises that "Man was born free, and everywhere he is in chains."

According to Rousseau (2002), conflict was introduced when forms of ownership started manifesting. As the population increased, the means of satisfying one's needs changed because families began to live as communities. People who owned less started working for those who have means of production such as land to get a reward (Friend, 1995). This way, the fortunate ones managed to amass a lot of private property and violated the necessity for others to own as much land as his subsistence require (Rousseau, 2002). As a result, those who were not so fortunate started realizing their misery, poverty and trouble.

As time passed, the division of labour was institutionalized. At the same time, the competition began manifesting its repercussions as some people started accumulating lots of property more than their counterparts (Rousseau, 2002). Its baffled Rousseau that some people amassed a great deal of property and took over immense territories to rob the entire human race of the opportunity to own basic assets. Human greed and avarice resulted in envy, shame and jealousy. It caused inequality to rise extensively (Rousseau, 2002). As the vices got pronounced and social classes intensified, poor people begrudged the successful ones more than ever before and endangered their rights and property.

The insecurity of the wealthy class, perpetuated by the poor people, compelled the rich to think of creating an authority to safeguard their private property. Therefore, according to Rousseau (2002), the civil government was formed to serve the interests of the bourgeoisie and not the proletariat. The formation of the government under the social contract serves to formalize the inequalities resulting from the division of labour (Rousseau, 2002). Even if the contract may seem to be for everyone, it is basically for those who are wealthy and not the poor. The realisation that the freedoms enjoyed by human beings were restricted by social realities compelled Rousseau to argue that man was born free but is found bound in chains wherever he goes (Rousseau, 1987; Friend, 1995).

In a nutshell, the social contract comes into place as free individuals come together to set up an authority that oversees their activities and safeguard their liberties and property (Rousseau, 2002). It is an act that comes into effect when a collective majority decides to renounce the rights and freedoms they had in the state of nature. The government acts as the trusted sovereign 
body which directs the society for the common good (Rousseau, 2002; Verschoor, 2015; Santilli, 1982). The government and society that establish it play reciprocal roles. For the citizens to fully reap the benefits of the social contract, Rousseau contends that they ought to be forced to be free.

\section{The Social Contract in The Contemporary Era}

In modern times, social contract manifests itself when people elect a government. By voting in free and fair elections, citizens collectively transfer their rights to their elected government in exchange for protection (Hobbes, 1651). The elections demonstrate explicit consent to establish an authority to defend the right of the citizens. In a democratic system, elections are supposed to be free and fair (Beetham, 1994). Through elections, citizens relinquish their rights and entrust the government with overseeing their lives (Santilli, 1982). However, Mapunye (2016) argues that elected representatives in Africa fail to account to voters hence they suffer from a legitimacy crisis. Once in office, elected officials forget the mandate assigned to them by the voters.

The modern application of the social contract differs slightly from the one propounded by Hobbes, Locke and Rousseau. The traditional contract in a state of nature begun with a partially implicit convention (Maphunye, 2016). David Hume simplifies the understanding of the social contract as it originally took place (Skyrms, 2008). The metaphor portrays a picture of two men using oars to propel a boat. They may propel the boat with or without convention or agreement but they do not exchange vows or give promises to each other (Skyrms, 2008). Conversely, the modern-day social contract is explicit and full of promises, particularly in a democratic system. Political parties that form governments are mostly elected and instituted based on their claims to deliver (Abuya, 2009). Their pledges to the masses are often expressed through the political parties' manifesto and vow which take place during an inauguration (Eder, Jenny \& Müller, 2017). Thus, the modern form of government is based neither on contractarianism nor Locke's voluntarianism (Locke, 1980). It centres, rather, on contractualism (Verschoor, 2015).

Most governments are signatories to the United Nations International Covenant on Civil and Political Liberties (Datton, 2017). The covenant enshrines the right to liberty and security of persons (The United Nations General Assembly, 1966). It also enshrines the right to freedom of conscience, thought and religion. It permits individuals to have the right to freedom of expression. Freedom of speech allows the media and non-governmental organizations (NGOs) to act as watchdogs and advocate for those abused by others or their government. Individuals are permitted to assemble together without unnecessary restrictions. The right to freedom of association is the basis for civil society since it has to mobilize the people for action whenever a government abuses its authority. Article 23 of the International Covenant on Civil and Political Liberties states that society and state have the obligation to protect a family. Article 25 of the same covenant authorises all eligible citizens to vote and be elected (The United Nations General Assembly, 1966). The same rights and freedoms are protected in the African Charter and People's Rights (African Charter and people's Rights, 1990).

The constitutions of most countries African also enshrine the aforementioned rights to protect lives, liberty and property. The constitution of Kenya and Lesotho, for instance, guarantees the right to life, liberty, free movement, freedom from inhumane treatment, freedom of association, freedom of expression, freedom from the seizure of property, right to participate in government and right to equality before the law (Lesotho. Const. chptr. 4-20; Kenya. Const. chptr. 4; part. 2).

The social contract presents an obligation to both the state and individuals in society. The government is imbued with the authority to govern while citizens' rights and freedoms are guaranteed. When citizens elect a government, they attach expectations to their votes. The manifesto of a political party they elect sets the basis for their hopes (Eder, Jenny \& Müller, 
2017). Other expectations come from the pledges made by governments publicly while others are implicit obligations. Citizens have implicit and explicit responsibilities to the government as well. They vote, pay tax and abide by laws. At the same time, they expect their government to provide public goods, provide infrastructure and health facilities (O'Brien, Hayward \& Berkes, 2009). However, once African leaders are inaugurated, they insulate themselves from the voters and govern from a distant (Kali, 2020).

\section{Violations of The Social Contract by Governments}

African states disregard the social contract at the detriment of their people. Millions of civilians suffer from conflicts and atrocities perpetrated by governments. Fighting, insecurity and lack of state protection caused a devastating humanitarian crisis among Somalians in 2018 (Human Rights Watch, 2019a). Around 2.6 million citizens are internally displaced due to the Somalian crises (Human Rights Watch, 2019a). Similarly, in Cameroon, at least 681000 are internally displaced and 3000 lives of demonstrators and civilians lost in the Anglophone crisis (Caxton, 2017; Ntui, 2020). Security forces destroy the property of protesting Anglophones and burn down their houses (Human Rights Watch, 2019b). Equally, Human Rights Watch (2019c) reports that in Democratic Republic of Congo (DRC), the government repressed and violated the rights of opposition leaders, supporters, human rights activists, journalists and peaceful protestors in 2018. More than 4.5 million citizens are displaced from their homes and 130000 are refugees while many others are arbitrarily detained.

In Mali, human rights violations soared significantly in 2018. According to the Human Rights Watch (2019d), the atrocities committed were attributed to the Islamist groups and the army which killed civilians. Most of the crimes committed by the latter happened during counterterrorism operations. Meanwhile, intercommunal conflict led to the death of hundreds of civilians and exacerbated the humanitarian crisis. Around 2018, the Malian army allegedly took 60 civilian lives that were blamed for supporting Islamist groups and many others were subjected to forced disappearance, torture and inhumane treatment. The insecurity in the country led to the mismanagement of the judiciary and compelled its personnel to abandon jobs (Human Rights Watch, 2019d).

In Equatorial Guinea, violations of human rights and unfair trials have become commonplace. According to Human Rights Watch (2019e), civil society organizations are repressed, some media houses are run by people close to the president and others face intimidation while opposition parties are suppressed. In 2018, the police detained 147 opposition party members, sentenced 28 of them to 30 years in prison and issued an order for the party to be dissolved. After severe torture that led to the death of two inmates, the government pardoned and freed the rest (Human Rights Watch, 2019e).

In Nigeria, the government cannot fully guarantee the security of civilians. The Human Rights Watch (2019f) sustained that abductions, suicide bombings and arbitrary attacks on civilians are persistent. The operations of Boko Haram in 2019 led to the death of 1200 civilians and displaced nearly 200, 000 in 2018 in the northeast (Human Rights Watch, 2019f). Meanwhile, the state aggravated the plight of Nigerians through arbitrary detention and torture of civilians. However, civil society organizations frequently expose these violations of the social contract. Where there is no conflict, governments threaten civil and political liberties in several ways. For instance, Zimbabwe, Cameroon, Benin and Ethiopia shut down the internet service with the aim of forestalling protests (Ayalew, 2020; Repucci, 2020; VOA, 2019). Likewise, Algeria, Sudan, Burundi, Togo, Zambia and Senegal responded with violence against citizens who demonstrate for their rights. Equally, the government of Lesotho threatened journalists and arbitrarily shut down radio stations considered to be critical of its own administration (Kali, 2019; Mat'sasa, et al., 2019). 
Since democratic governments are established through elections, the very mechanism that set them up is used to dismantle them. It makes perfect sense to believe that a voter can hold the elected officials accountable through periodic elections (Hellwig \& Samuel, 2008). Besides, John Locke's philosophy maintains that citizens can replace a government that no longer upholds the general will. However, elections are not only rigged but their principles are also perverted in many countries (Adejumobi, 2000). According to Okello (2018), in Zimbabwe, Cameroon and DRC, opposition leaders cried foul because the incumbents rigged elections. Hence, the very act that set up an authority is not always the best mechanism to renounce it.

When a government perverts electoral precepts and rigs elections, the local courts are the best available recourse. For instance, in Kenya, Mozambique and Malawi, the verdict of the courts annulled the presidential election results in 2017, 2019 and 2020 respectively (Heyl, 2020). Eventually, the opposition won the rerun of the presidential elections after the court overturned the May 2019 results (Gondwe, 2020). However, given the number of African countries that often cry foul, lodge legal complaints against election outcomes and lose cases in courts, these aforementioned cases are sporadic. Where elections are not rigged, some voters are excluded from voting, elections are postponed, constitutional barriers are manipulated and watchdogs are co-opted or harassed (Byiers \& Ronceray, 2019). Besides, the courts seem to be ineffective in the face of the power of the "big man" (Bratton \& Logan, 2006; Bratton \& Van de Walle, 1994). Under these debilitating circumstances, it is difficult for civil society organizations to mobilize the citizens for protests against any regime that no longer fulfils its responsibilities (Verschoor, 2015). The limitations of the local courts make regional bodies and international courts the last resort of recourse in case of an unsuccessful social contract.

According to Hauk and Desmidt (2017), the success stories of the African Peace and Security Architecture of the African Union (AU) are too limited to guarantee civil and political liberties of Africans. Jaye (2000) contends that the intervention of Economic Community of West African Countries (ECOWAS) in Liberia failed to yield expected outcomes because of the incapacity and institutional constraints of the Organization of African Unity (OAU). However, after the transformation of OAU to AU, ECOWAS organized successful peace resolutions in Gambia, Mali, Burkina Faso and Côte d'Ivoire (Kali, 2019). Quite the contrary, Southern African Development Community's interventions in Lesotho, DRC and Zimbabwe are riddled with flaws- the only exception to this being its intervention in Madagascar (Cawthra, 2010; Kadima, 1999; Kali, 2019). Similarly, the Intergovernmental Authority on Development has not attained much from its interventions in Somalia (Hassan, 2018).

African Union has established a court to resolve the disputes and safeguard the liberties of African civilians. Its court is based in Arusha, Tanzania. The protocols establishing the African Court of Justice and Human Rights came into force on 25 January 2004 (African Court of Human and Peoples' Rights, 2020). Up to date, the court has so far received 250 applications from individuals and 15 from NGOs and finalized 90 of them (African Court of Human and Peoples' Rights, 2020).

According to Cannon, Pkalya and Maragia (2017), the International Criminal Court (ICC) was founded on 17 July 1998 and was backed by African states. The ICC opened cases for several African country leaders which include the following: Kenya, Burundi, Uganda, DRC, Central African Republic, Mali, Libya and Côte d'Ivoire (International Criminal Court, n.d). Although it appears as though the court is serving the interest of civilians, African leaders have condemned it. They believe that it is just a tool by superpowers to charge Africans. In 2014, President Yoweri Museveni urged African countries to withdraw their membership from the court (Cannon, Pkalya \& Maragia, 2017). The plausibility and credibility of the ICC circulate around scholarly debates and among politicians. Without engaging the arguments, the author maintains that an instrument is good to the extent that it accomplishes the task it was designed 
to perform. Its main function is to judge those who commit crimes against humanity and it has been doing so (Cannon, Pkalya \& Maragia, 2017).

\section{The Forgotten Responsibility of Civil Society Organizations}

Civil society organizations in Africa appear not to be interested in serving as a buffer between the state and society. They seem not to have fully grasped the political and civil liberties made accessible through democracy. They do not regularly hold ministers, presidents and leaders accountable (Bratton \& Logan, 2006). The essence of democracy is manifested when leaders are answerable to the public for their actions. Accountability is the cornerstone of democracy since it helps ensure that governments refrain from abusing their power and violating individual rights. Looking at the number of cases submitted to the African Court by NGOs, it is obvious they are either complacent or not zealous of influencing democratic consolidation. Individuals submitted many cases to the court but NGOs deposited only 12 since 2004 (African Court of Human and Peoples' Rights, 2020). In spite of police brutality during protests, a government clampdown on civilians and common abuses of power after elections, NGOs are not flooding the African court with appeals and complaints (Human Rights Watch, 2019e). This implies that they have not exhausted local remedies or they are unworried by the state of affairs.

The African civil society organizations are politicized, partisan and polarize the society instead of holding governments accountable. Nyamnjoh (2009) sustains that they divide citizens based on their political affiliations and ethnic group. The media's rhetoric contrasts its practice since their professional values do not coincide with the expectations of the people they purport to serve. In Cameroon, the NGOs are manipulated by politicians to redirect their developments and assistance to their constituencies (Nyamnjoh, 2009). Similarly, in Lesotho, some media houses, journalists and NGOs are known to be partisan (Mat'sasa, et al., 2019). It is virtually unpractical for politicized civil society organizations to be critical, hold political officers accountable and deter their abuses of power. Civil society organizations may only condemn acts of corruption when they are not done by their preferred political parties.

\section{Conclusions and Recommendations}

The social contract was established out of rationality. After weighing losses and benefits, it was realized that it is worthwhile to establish a government. A governed society was esteemed over anarchy. The latter proved to be detrimental to human freedoms, property and life more than the former. In the contemporary era, Africans pursue the social contract through periodic elections where they chose a government to govern over them. In a democratic system, a leader is elected based on the manifesto, pledges and promises to the society. The government adopts a constitution and signs international covenants that promise to safeguard civil and political liberties of its people. Inversely, citizens pay taxes to their government and abide by the laws. They also transfer part of their rights so that their leaders can impose sanctions and penalties on transgressors. In brief, the social contract represents a reciprocal deal between society and its government.

African governments largely violate the social contract. They arrest citizens arbitrarily, subject them to forced disappearance, torture and inhumane treatment. Most of the civilians' property, freedoms and lives are not guaranteed by the government. The leaders disregard international conventions, the constitutions and promises made to the voters and abuse their powers. Under such deplorable circumstances, citizens unsuccessfully try to revolt or change the government. The media and civil society organizations expose the deficits of authorities and appeal to courts. Meanwhile, the voters attempt to change leaders through elections to no avail. The incumbent governments co-opt or suppress civil society organizations, repress opposition parties and rig elections. They also subvert and sabotage the judicial system. 
Since the benefits of the social contract outweigh anarchy, the latter remains as the most prudent and noble choice. Although it seems as though the repercussions of the social contract were underrated, there seems to be no other better alternative. Even though coercion and repression perpetuate the woeful catastrophe of the African people, the status quo can be transformed. As witnessed from the verdict of the Kenyan and Mozambican courts and ICC, mechanisms of holding the perpetrators accountable are not fully exhausted.

African Union together with its partners should strengthen the regional and international court. Instead of withdrawing from the ICC, African leaders have to find a way of improving its operations. The AU should reassess the operations of the African Court and ensure that it becomes credible to individuals and society. This will spur the NGOs to flood the court with communications. Once regional bodies strengthen the African court, leaders will refrain from undermining the operations of the local courts. This will indirectly strengthen national judicial systems. Lastly, civil society organizations have to reassess their autonomy and commitment to act as a buffer between the people and the leaders. These will consequently increase the benefits reaped from the social contract and the merits will outweigh demerits.

\section{Acknowledgements}

The author would like to acknowledge the invaluable comments of Mr. Fred Ernest Nasubo, Brivery Siamabele (Ph.D candidates at the Pan African University Institute of Governance Humanities and Social Sciences) and Thuso Mosabala (a Masters' student). Their contribution to this article is highly valued.

\section{References}

Abuya, E. (2009). Consequences of a flawed presidential election. Legal Studies, 29(1), 127158. doi:10.1111/j.1748-121X.2008.00110.x

Adejumobi, S. (2000). Elections in Africa: A Fading Shadow of Democracy? International Political Science Review / Revue Internationale De Science Politique, 21(1), 59-73.

African Commission on Human and Peoples' Rights. (1990). The African Charter on Human and People's Rights. New York: United Nations.

African Court on Human and Peoples' Rights. (2020, March 15). Cases. Retrieved June 10, 2020, from https://en.african-court.org/index.php/cases\#statistical-summary

Ayalew, Y. E. (2020, April 5). Internet shutdowns have disrupted millions of lives in Ethiopia. Quartz Africa. https://qz.com/africa/1832807/ethiopias-internet-shutdowns-are-disruptingmillions-of-lives/

Beetham, D. (1994). Conditions for democratic consolidation. Review of African Political Economy, 21(60), 157-172. https://doi.org.10.1080/03056249408704053

Bratton, M., \& Van de Walle, N. (1994). Neopatrimonial Regimes and Political Transitions in Africa. World Politics, 46(4), 453-489. https://doi.org.10.2307/2950715

Bratton, M., \& Logan, C. (2006). Voters but not yet citizens: the weak demand for political accountability in Africa's unclaimed democracies (26). AfroBarometer. https://afrobarometer.org/sites/default/files/publications/Working\%20paper/AfropaperNo 63.pdf

Cawthra, G. (2010). The Role of SADC in Managing political crisis and conflict: The Cases of Madagascar and Zimbabwe. Friedrich-Ebert-Stiftung. https://library.fes.de/pdffiles/bueros/mosambik/07874.pdf 
Caxton, A. S. (2017, July 24). The Anglophone dilemma in Cameroon - ACCORD. ACCORD. https://www.accord.org.za/conflict-trends/anglophone-dilemma-cameroon/

D'Agostino, F., Gaus, G., \& Thrasher, J. (2019). Contemporary approaches to the social contract (Stanford encyclopedia of philosophy). In E. Zalta (Ed.), Stanford Encyclopedia of Philosophy. https://plato.stanford.edu/entries/contractarianism-contemporary/

Dutton, Y. (2017). Commitment to international human rights treaties: The role of enforcement mechanisms. U. Pa. J. Intel' L, 34(1), 1-66. https://doi.org/10.31228/osf.io/jvke7

Eder, N., Jenny, M., \& Müller, W. C. (2017). Manifesto functions: How party candidates view and use their party's central policy document. Electoral Studies, 45, 75-87. https://doi.org/10.1016/j.electstud.2016.11.011

Friend, C. (1995). Social contract theory. In J. Fieser \& B. Downden (Eds.), Internet encyclopaedia of philosophy. An encyclopaedia of philosophy articles written by professional philosophers. https://www.iep.utm.edu/soc-cont/\#H2

Gondwe, G. (2020, June 27). Opposition Wins Historic Rerun of Malawi's Presidential Vote. U.S. News. https://www.usnews.com/news/world/articles/2020-06-27/malawi-leaderblasts-vote-rerun-as-opposition-poised-to-win

Haskin, J. M. (2005). The tragic state of the Congo: From decolonization to dictatorship. Algora Publishing.

Hassan, A. (2018). The Effectiveness of IGAD in promoting Regional Diplomacy: A Case Study of the Somalia Peace Process [Unpublished master's thesis]. The University of Nairobi Institute of Diplomacy and International Studies.

Hauck, V., \& Desmidt, S. (2017). Conflict management under the African Peace and Security Architecture (211). https://ecdpm.org/wp-content/uploads/DP211-Conflict-ManagementAPSA-Desmidt-Hauck-April-2017.pdf

Hellwig, T., \& Samuels, D. (2008). Electoral Accountability and the Variety of Democratic Regimes. British Journal of Political Science, 38(1), 65-90.

Heyl, C. (2020, February 28). As Malawi Shows, African Courts Are Slowly Becoming More Independent. World Politics Review. https://www.worldpoliticsreview.com/articles /28567/as-the-malawi-election-showed-african-courts-are-slowly-becoming-moreindependent

Hobbes, T. (1651). Leviathan or the Matter, Forme, \& Power of a Common-wealth Ecclesiasticall and Civill. Green Dragon.

Human Rights Watch. (2019a, January 17). World report 2019: Rights trends in Somalia. https://www.hrw.org/world-report/2019/country-chapters/somalia

Human Rights Watch. (2019b, January 23). World report 2019: Rights trends in Cameroon. https://www.hrw.org/world-report/2019/country-chapters/cameroon

Human Rights Watch. (2019c, January 17). World report 2019: Rights trends in Democratic Republic of Congo. https://www.hrw.org/world-report/2019/country-chapters/democraticrepublic-congo

Human Rights Watch. (2019d, January 17). World report: Rights trends in Mali. Human Rights Watch. https://www.hrw.org/world-report/2019/country-chapters/mali

Human Rights Watch. (2019e, January 18). World report 2019: Rights trends in Equatorial Guinea. https://www.hrw.org/world-report/2019/country-chapters/equatorial-guinea 
Human Rights Watch. (2019f, January 17). World report 2019: Rights trends in Nigeria. https://www.hrw.org/world-report/2019/country-chapters/nigeria

International Criminal Court. (n.d.). International Criminal Court. https://www.icccpi.int/Pages/Main.aspx\#

Jaye T. (2000). ECOWAS and Liberia: Implications for Regional Intervention in Intra-state Conflicts. In: Bakut B.., Dutt S. (eds) Africa at the Millenium. Palgrave Macmillan.

Kadima D. (1999). The DRC and Lesotho crises: Some lessons for the SADC, Lesotho Social Science Review, 5(1).

Kali, M. (2019). Democratic Reversals: Examining the Role of the Armed Forces and the Southern African Development Community in Lesotho. International Journal of Research and Innovation in Social Science; 03, 11, 2454-1686.

Kali, M. (2020). Challenges and Prospects of Decentralisation in Lesotho. International Journal of Humanities, Art and Social Studies, 5(2), 11-20.

Kenya. Constitution. Chptr. 4. Part. 2 https://www.wipo.int/edocs/lexdocs/laws/en/ ke/ke019en.pdf

Kuwonu, F. (2019, March). Crisis worsens in Cameroon. Welcome to the United Nations. https://www.un.org/africarenewal/magazine/december-2018-march-2019/crisis-worsenscameroon

Lesotho. Constitution. Chptr. 4-8. https://sfcollege.libguides.com/apa/other

Locke, J. (1980). Second treatise of government. Macpherson C. B. (Ed.). Hackett Pub. Co.

Locke, J. (2003). Two treatises of government, and; A letter concerning toleration. I. Shapiro (Ed.). Yale University Press.

Maphunye, K. (2016). Are Africa's elections underscored by accountability and the social contract? Unisa. http://uir.unisa.ac.za/handle/10500/21001

Mat'sasa T., Sithetho M., \& Wekesa B. (2019). The Lesotho National Dialogue and Stabilization Project Media Sector Reforms. https://www.gov.ls/wpcontent/uploads/2019/11/REVISED-MEDIA-SECTOR-REFORMS-REPORT.pdf

Ntui, A. E. (2020). Cameroon. Crisis Group. https://www.crisisgroup.org/africa/centralafrica/cameroon

Nyamnjoh, F. (2009). Africa's Media: Between Professional Ethics and Cultural Belonging. fesmedia Africa Friedrich-Ebert-Stiftung. https://library.fes.de/pdf-files/bueros/africamedia/07366.pdf

O'Brien, K. Hayward, B. \& Berkes, F. (2009). Rethinking social contracts: building resilience in a changing climate. Ecology and Society 14(2), 12.

Okello, C. (2018, November 5). Can democracy work in Africa? RFI. http://www.rfi.fr/en/20181106-spot-afr-06-11-18-Zimbabwe-Cameroon-DRC-doesdemocracy-work-Africa

Repucci, S. (2020, February 5). A leaderless struggle for democracy. Freedom House. https://freedomhouse.org/report/freedom-world/2020/leaderless-struggle-democracy

Romaniuk, S., \& Grice, F. (2018, November 15). Norms, norm violations, and IR theory. EInternational Relations. https://www.e-ir.info/2018/11/15/norms-norm-violations-and-irtheory/ 
Ronceray M., \& Byiers, B. (2019). Elections in Africa - Playing the game or bending the rules? (261) ecdpm. https://ecdpm.org/wp-content/uploads/Elections-Africa-Playing-GameBending-Rules-ECDPM-Discussion-Paper-261.pdf

Rousseau, J. J. (2002). The Social Contract and The First and Second Discourses. (ed.) S. Dunn. Yale University Press.

Santilli, P. C. (1982). The family and social contract theory. Philosophy, Children, and the Family, 17-28. https://doi.org/10.1007/978-1-4613-3473-6_2

Simmons, AJ (1979). Moral Principles and Political Obligations. Princeton University Press.

Skyrms, B. (2008). The Social Contract Naturalized. In M. Fleurbaey, M. Salles, \& J. Weymark (Eds.), Justice, Political Liberalism, and Utilitarianism: Themes from Harsanyi and Rawls (pp. 334-350). Cambridge University Press. doi:10.1017/CBO9780511619595.015

The United Nations General Assembly. (1966). International Covenant on Civil and Political Rights. Treaty Series, 999, 171.

Verschoor, M. (2015). The democratic boundary problem and social contract theory. European Journal of Political Theory, 17(1), 3-22. https://doi.org/10.1177/1474885115572922

VOA. (2019, April 23). 'African governments violating civil liberties, individual freedoms'. VOA. https://voazimbabwe.com/a/freedoms-vanish-in-africa-as-people-/4888416.html 